\title{
Aflatoxin production and in vitro toxicity of Aspergilli section Flavi isolated from air samples collected from different environments
}

\author{
Daniela Jakšić ${ }^{1}$ - Sándor Kocsubé ${ }^{2}$ Ottó Bencsik ${ }^{2}$ - Anita Kecskeméti ${ }^{2} \cdot$ András Szekeres $^{2} \cdot$ Dubravko Jelić $^{3}$. \\ Nevenka Kopjar ${ }^{4}$ - Csaba Vágvölgyi ${ }^{2}$ · János Varga ${ }^{2} \cdot$ Maja Šegvić Klarić ${ }^{1}$
}

Received: 14 August 2018 / Revised: 4 February 2019 / Accepted: 22 February 2019 / Published online: 12 March 2019

(C) Society for Mycotoxin (Research Gesellschaft für Mykotoxinforschung e.V.) and Springer-Verlag GmbH Germany, part of Springer Nature 2019

\begin{abstract}
Aspergilli section Flavi, originally isolated from air samples collected from inhabited apartments (AP), unoccupied basements (BS), and processing facilities of a grain mill $(\mathrm{GM})$, were analyzed for their potential to produce aflatoxin $\mathrm{B}_{1}\left(\mathrm{AFB}_{1}\right)$ on solid media. The isolates were further characterized with regard to their cytotoxic, genotoxic, and pro-inflammatory properties in vitro. Aspergilli were identified based on partial calmodulin $(\mathrm{CaM})$ gene sequencing; the producing capacities of isolates were analyzed by HPLC/FLD and confirmed by genes in biosynthesis (aflR, norA, omtA). In the grain mill, the Aspergilli section Flavi (up to $\left.1.3 \times 10^{6} \mathrm{cfu} / \mathrm{m}^{3}\right)$ dominated by $\mathrm{AFB}_{1}$-producing Aspergillus flavus $(71 \%, 4.5-5254 \mathrm{ng} / \mathrm{ml})$ which showed a serious health risk for workers. Living environments were not relevant sources of exposure. After $24 \mathrm{~h}, \mathrm{AFB}_{1}(1-100 \mu \mathrm{mol} / \mathrm{l})$ reduced cell viability (MTT test) in both A549 cells and THP-1 macrophage-like cells without reaching $\mathrm{IC}_{50}$. In A549 cells, the extract of the $\mathrm{AFB}_{1^{-}}$ producing A. flavus significantly decreased cell viability but not below $50 \%$. THP-1 macrophage-like cells were more sensitive to both extracts, but $\mathrm{IC}_{50}$ was obtained only for the $\mathrm{AFB}_{1}$-producing strain $\left(0.37 \mathrm{mg} / \mathrm{ml} ; \mathrm{AFB}_{1} 2.78 \mu \mathrm{mol} / \mathrm{l}\right)$. $\mathrm{AFB}_{1}(1$ and $10 \mu \mathrm{mol} /$ 1) induced significant DNA damage (tail intensity, alkaline comet assay) in A549 cells in contrast to Aspergilli extracts. $\mathrm{AFB}_{1}$ elevated IL-6 and IL-8, while Aspergilli extracts increased IL-1 $\beta$, TNF- $\alpha$, and IL-17 release in THP-1 macrophages (ELISA). Chronic exposure to $\mathrm{AFB}_{1}$ and/or other metabolites in airborne A. flavus from occupational environments may stimulate epithelial damage of airways accompanied by lowered macrophage viability.
\end{abstract}

Keywords Airborne fungi $\cdot$ Aflatoxin $\mathrm{B}_{1} \cdot$ Cytotoxicity $\cdot$ DNA damage $\cdot$ Cytokines

\section{Introduction}

The Aspergillus section Flavi comprises several species widely distributed in the environment. These species can be separated into two groups based on their economic importance and impact on human and animal health. The first group includes the non-producing aflatoxin species Aspergillus oryzae,

Maja Šegvić Klarić

msegvic@pharma.hr

1 Department of Microbiology, Faculty of Pharmacy and Biochemistry, University of Zagreb, Schrottova 39, 10000 Zagreb, Croatia

2 Department of Microbiology, Faculty of Science and Informatics, University of Szeged, H-6726, Szeged Közép fasor 52, Hungary

3 Fidelta Ltd., Prilaz baruna Filipovića 29, 10000 Zagreb, Croatia

4 Mutagenesis Unit, Institute for Medical Research and Occupational Health, Ksaverska cesta 2, 10000 Zagreb, Croatia
Aspergillus sojae, and Aspergillus tamarii used in oriental food fermentation (Campbell-Platt 1994). Genetically modified A. oryzae strains are used for the production of enzymes, including lactase, pectin esterase, lipase, protease, and xylanase (Pariza and Johnson 2001). The second group includes aflatoxin-producing species Aspergillus flavus, Aspergillus parasiticus, and Aspergillus nomius, which contaminate and damage various pre-harvested and stored agricultural products (Perrone et al. 2014). In the past decade, the production of aflatoxins was also reported in newly described species Aspergillus arachidicola, Aspergillus bombycis, Aspergillus minisclerotigenes, Aspergillus parvisclerotigenus, Aspergillus pseudocaelatus, Aspergillus pseudonomius, Aspergillus pseudotamari, Aspergillus togoensis, Aspergillus mottae, Aspergillus sergii, and Aspergillus transmontanensis (Varga et al. 2011; Soares et al. 2012).

Aflatoxins are known hepatotoxic mycotoxins with carcinogenic, genotoxic, and teratogenic properties in both humans and animals (Bennett et al. 2003). Among these mycotoxins, 
aflatoxin $\mathrm{B}_{1}\left(\mathrm{AFB}_{1}\right)$ is the most toxic as well as the most frequently occurring aflatoxin in agricultural products (Varga et al. 2011).

In general, aflatoxins are principally produced by A. flavus and A. parasiticus; A. flavus mainly produces $\mathrm{AFB}_{1}$ and $\mathrm{AFB}_{2}$, while most $A$. parasiticus isolates produce $\mathrm{AFG}_{1}$ and $\mathrm{AFG}_{2}$ in addition to $\mathrm{AFB}_{1}$ and $\mathrm{AFB}_{2}$. However, A. flavus is considered more invasive and out-competes $A$. parasiticus when both species are present in soil (Perrone et al. 2014). Aflatoxigenic strains of A. flavus are most widespread in tropical and subtropical areas. However, in recent years, a more frequent occurrence of aflatoxin producers has been detected in temperate-climate regions, associated with current climate change. Air humidity changes (abundant rain, droughts), increase in temperature, and increased $\mathrm{CO}_{2}$ concentration directly affect the expression of regulatory $(a f l R)$ and structural genes ( $a f l D$ ) involved in the biosynthesis of $\mathrm{AFB}_{1}$ and, thus, correlate with its biosynthesis (Paterson and Lima 2010; Medina et al. 2014).

Next to A. fumigatus, A. flavus is the second most frequent cause of invasive and non-invasive aspergillosis in humans; it may also cause sinusitis, cutaneous and wound aspergillosis, as well as otitis and keratitis (Hedayati et al. 2007; Manikandan et al. 2013).

Taking into account the aflatoxigenic ability of the listed Aspergilli section Flavi, particularly A. flavus, as well as its role in the etiology of several diseases in humans, an accurate identification of the species would provide fundamental information concerning their aflatoxigenic and pathogenic properties (Godet and Munaut 2010). Several molecular genetic techniques have been developed to distinguish the Aspergillus species in the section Flavi; Varga et al. (2011) proposed a polyphasic approach, including morphological characters, extrolite data, and partial calmodulin $(\mathrm{CaM}), \beta$ tubulin (BenA), and ITS sequences as well as the presence of genes involved in aflatoxin biosynthesis.

Since the discovery of aflatoxins, the hepatotoxic action of $\mathrm{AFB}_{1}$ has been mainly studied in various experimental models through $\mathrm{AFB}_{1}$-contaminated food consumption (Bennett et al. 2003). However, a link between $\mathrm{AFB}_{1}$ inhalation in an industrial setting and liver or lung cancer incidence and mortality has been suggested by several investigations (Olsen et al. 1988; Viegas et al. 2012). Taking into account the lack of data on human exposure to fungal burden in urban homes and occupational settings in our country, recently, we conducted a year-round investigation of airborne fungi in living (apartments, basements) and occupational (grain mill) indoor environments in Croatia with special attention to Aspergillus sections Flavi, Nigri, and Versicolores due to their known pathogenic and/or mycotoxin-producing properties (Jakšić Despot and Šegvić Klarić 2014,b). Based on morphological methods, Aspergilli sections Flavi and Nigri were recovered in the highest frequencies $(50-100 \%$ and $15-55 \%$, respectively) from samples taken in the grain mill, while Aspergilli section Versicolores was more abundant in apartments and basements (10-65\%) (Jakšić Despot and Šegvić Klarić 2014,b). Before appropriate molecular identification methods for species assigned to these sections, indoor air isolates were usually reported as A. flavus, A. niger, or A. versicolor (Samson et al. 2014). As we previously noted, accurate identification of the Aspergillus species is fundamental with regard to their toxigenic and/or pathogenic properties (Godet and Munaut 2010). Thus, herein, we described the species diversity of Aspergillus sections Nigri (Jakšić et al. 2018) and Versicolores (Jakšić Despot et al. 2016) using calmodulin sequence-based methods, their ability to produce fumonisin $\mathrm{B}_{2}$ and sterigmatocystin, respectively, and to explore toxic potential of Aspergilli extracts in comparison with these mycotoxins alone. To further extend knowledge on Aspergillus section Flavi biology and toxicology, the present study aimed to explore the species diversity of isolated strains using a polyphasic approach (morphological methods, $\mathrm{CaM}$ sequence, and presence of genes taking part in aflatoxin biosynthesis) and confirm aflatoxin-producing abilities in Aspergilli extracts by HPLC/FLD.

Some studies showed that $\mathrm{AFB}_{1}$ alone induces several toxic events in human airways, including damage of airway epithelial cells, decrease of the ciliary beat frequency (Lee et al. 2016), DNA damage due to formation of exo-AFB1-8,9-epoxide by human lung microsomes (Kelly et al. 1997) as well as takes a part in inflammation (Lee et al. 2016; Luongo et al. 2014). However, the effects of inhaled aflatoxin-producing fungi on the airway epithelium have not been wellcharacterized so far.

As A. flavus was among the most abundant species in the grain mill, it was justified to explore the cytotoxic, genotoxic, and immunomodulatory properties of $\mathrm{AFB}_{1}$-producing and $\mathrm{AFB}_{1}$-non-producing A. flavus extracts in contrast to $\mathrm{AFB}_{1}$ alone in order to clarify whether particular toxic properties of Aspergilli could be attributed to $\mathrm{AFB}_{1}$. This was carried out using human lung adenocarcinoma A549 cells and macrophages derived from human leukemic monocyte THP-1 cells as experimental models.

\section{Materials and methods}

\section{Chemicals and media}

Methanol, acetonitrile, methylene chloride, ethyl acetate, and $\mathrm{n}$-hexane for sample preparation and eluents were purchased from VWR (Debrecen, Hungary). Formic acid, trifluoroacetic acid, and aflatoxin $\mathrm{B}_{1}$ standard were obtained from SigmaAldrich (Budapest, Hungary). Deionized water for both sample preparation and high-performance liquid chromatography (HPLC) runs was produced by Merck Millipore Milli-Q 
Gradient A10 water purification equipment (Budapest, Hungary). Dichloran 18\% glycerol agar (DG-18), Czapek Yeast Agar (CYA), and Malt Extract Agar (MEA) were purchased from Oxoid (Hampshire, UK). Media for cell culture maintenance, including RPMI 1640, fetal bovine serum (FBS), trypsin-EDTA, phosphate-buffered saline (PBS; $\mathrm{Ca}^{2+}$ and $\mathrm{Mg}^{2+}$ free), penicillin, and streptomycin were from Lonza (Basel, Switzerland). MTT reagent [3-(4,5-dimethylthiazol-2yl)-2,5-diphenyltetrazolium bromide], phorbol 12-myristate 13-acetate (PMA) ethidium bromide, acridine orange, normal melting point (NMP) agarose, low melting point (LMP) agarose, Triton X-100, Tris buffer, and dimethyl sulfoxide (DMSO) were purchased from Sigma-Aldrich (Deisenhofen, Germany). Dimethyl sulfoxide (DMSO) ethanol $\mathrm{HCl}, \mathrm{NaCl}$, $\mathrm{Na}_{2}$ EDTA, and $\mathrm{NaOH}$ were from Kemika (Zagreb, Croatia).

\section{Sampling areas}

The samples of airborne fungi were collected over a one-year period (2012) in two-month intervals at the processing facilities of a grain mill (GM) situated near Zagreb, Croatia, as well as in residential locations in the city which included two inhabited apartments (AP) and two unoccupied basements (BS) as well as outdoor air (ODA) as described in detail in Jakšić Despot and Šegvić Klarić (2014,b). In each period of sampling in GM, twenty samples were collected during milling operations at the site of grain/flour exchange, site of flour storage, site of sieving, and site of milling. In each AP (approximately $70 \mathrm{~m}^{2}$ ), samples were taken at five locations, including the kitchen, dining room, living room, bedroom, and bathroom, in duplicate. BSs were located in the same buildings as the AP, and residents used these spaces to store various items (e.g., wooden, metal, plastic, or glass materials). In each BS, samples were taken at five locations in duplicate. Samples of outdoor air were taken in proximity to indoor locations, and, during each sampling period, ten ODA samples were collected.

The sampling approach included collecting 20 indoor samples and 10 outdoor samples per each location and at a given time point. Altogether, 420 individual samples were taken.

\section{Sample collection}

Airborne fungi were sampled using an Airsampler Mas-100 Eco (Merck, Berlin, Germany) with 400 holes (hole to agar impactor, impaction velocity $10.8 \mathrm{~m} / \mathrm{s}$, and airflow rate $100 \mathrm{l} /$ min) and DG-18 agar plates (Samson et al. 2010). Because of the high contamination level, a volume of 101 was chosen for sampling in the GM, while a volume of 501 was applied at the other sampling locations. The plates were incubated at $25^{\circ} \mathrm{C}$ $\pm 0.2{ }^{\circ} \mathrm{C}$ in the dark for five days, after which the developed fungal colonies were counted, and results were expressed as colony-forming units per cubic meter $\left(\mathrm{cfu} / \mathrm{m}^{3}\right)$. Aspergilli were isolated on CYA and MEA agar plates (Samson et al. 2010). Isolates assigned to the Aspergillus section Flavi were purified and cultivated on CYA and MEA plates at $25^{\circ} \mathrm{C}$ in the dark for seven days. Morphological identifications were carried out according to literature (Samson et al. 2010).

\section{Determination of Aspergilli section Flavi genotypes}

Isolation of genomic DNA from mycelia grown in liquid YPD medium (1\% Bacto yeast extract, $1 \%$ Bacto peptone, $1 \% \mathrm{D}$ glucose) for five days was performed by Masterpure ${ }^{\mathrm{TM}}$ yeast DNA purification kit (Epicentre Biotechnologies, Madison, WI, USA) according to the manufacturer's instructions. The isolated DNA was diluted to $<1.000 \mathrm{ng}$ and used as template DNA in PCR reactions. A fragment of the calmodulin gene $(\mathrm{CaM})$, part of the transcriptional regulator of aflatoxin biosynthesis (aflR), norsolorinic acid reductase (norA or aflE), and O-methyltransferase gene (omtA, aflP) (Yu et al. 2004) were amplified using the primers specified in Table 1. Each PCR reaction mixture $(20 \mu \mathrm{l})$ contained $0.2 \mathrm{mmol} / \mathrm{l}$ deoxyribonucleotide triphosphate (dNTP), $0.2 \mu \mathrm{mol}$ of primers, $1 \mathrm{U}$ DreamTaq DNA Polymerase (Thermo Scientific, Madison, WI, USA) with the respective buffer (with $1.5 \mathrm{mmol} / \mathrm{l}$ $\mathrm{MgCl}_{2}$ ) (Thermo Scientific, Madison, WI, USA), nucleasefree water, and template DNA. Amplifications were performed using a Thermocycler T-100 (BioRad, Budapest, Hungary). The PCR cycling protocol consisted of 35 cycles, including an initial denaturation at $95^{\circ} \mathrm{C}$ for $2 \mathrm{~min}$ in the first and $20 \mathrm{~s}$ in the following runs, annealing temperature as specified in Table 1 for $20 \mathrm{~s}$, elongation at $72^{\circ} \mathrm{C}$ for $40 \mathrm{~s}$, and $2 \mathrm{~min}$ for the final elongation. The amplification products were analyzed by electrophoresis on $2 \%$ agarose gels using fluorescent dye GR Green (Excellgen, Budapest, Hungary), and the banding patterns were visualised under ultraviolet light $(254 \mathrm{~nm})$. In case of PCR products assigned to aflR, norA, and $o m t A$, the bands were scored as either present or absent for each A. flavus isolate. Partial CaM sequences were determined at the LGC Genomics GmbH (Berlin, Germany). Sequence analysis was performed by nucleotide-nucleotide BLAST similarity search at the website of the National Center for Biotechnology Information (http://www.ncbi.nlm. nih.gov/ BLAST), and sequences were, also, compared with our own sequence database. Species identification was determined from the lowest expected value of the BLAST output (Altschul et al. 1990).

\section{Preparation of Aspergilli section Flavi extracts and aflatoxin analysis}

Extracts of A. flavus isolates ( $n=65)$ were prepared and analyzed as described previously (Baranyi et al. 2015). Briefly explained, following a microextraction procedure according to Frisvad et al. (2007), three agar plugs (6 $\mathrm{mm}$ in diameter 
Table 1 The primers used in PCR

\begin{tabular}{|c|c|c|c|c|}
\hline Primer & Sequence $\left(5^{\prime}-3^{\prime}\right)$ & Annealing temperature $\left({ }^{\circ} \mathrm{C}\right)$ & Gene & Reference \\
\hline $\begin{array}{l}\text { Cmd-5 } \\
\text { Cmd-6 }\end{array}$ & $\begin{array}{l}\text { CCGAGTACAAGGARGCCTTC } \\
\text { CCGATRGAGGTCCATRACGTGG }\end{array}$ & $52-55$ & $\mathrm{CaM}$ & Hong et al. (2005) \\
\hline $\begin{array}{l}\text { Afl-F } \\
\text { Afl-R }\end{array}$ & $\begin{array}{l}\text { GGGATAGCTGTACGAGTTGTGCCAG } \\
\text { TGGKGCCGACTCGAGGAAYGGGT }\end{array}$ & $57-59$ & aflR & Varga et al. (2011) \\
\hline $\begin{array}{l}\text { Nor-1 } \\
\text { Nor-2 }\end{array}$ & $\begin{array}{l}\text { ACCGCTACGCCGGCACTCTCGGCA } \\
\text { GTTGGCCGCCAGCTTCGACACAGC }\end{array}$ & $64-66$ & norA & Criseo et al. (2001); Varga et al. (2011) \\
\hline $\begin{array}{l}\text { Omt-1 } \\
\text { Omt-2 }\end{array}$ & $\begin{array}{l}\text { GTGGACGGACCTAGTCCGACATCAC } \\
\text { GTCGGCGCCACGCACTGGGTTGGGG }\end{array}$ & $59-61$ & omtA & Geisen (1996); Varga et al. (2011) \\
\hline
\end{tabular}

each) were extracted using a mixture of organic solvents methanol/dichloromethane/ethyl-acetate $(1 / 2 / 3, v / v / v)$ supplemented with $1 \%$ of formic acid. The extracts were ultrasonicated, and the organic phases were separated, filtered through, and evaporated to dryness under a slight stream of nitrogen. Dry extracts were derivatized with trifluoroacetic acid (Fazekas et al. 2005). HPLC (Shimadzu, Japan) equipped with a fluorescence detector set at an excitation wavelength of $365 \mathrm{~nm}$ and an emission wavelength of $430 \mathrm{~nm}$ was used for $\mathrm{AFB}_{1}$ analysis. Separations were achieved on a LiChroCART $250 \times$ $4 \mathrm{~mm}, 5 \mu \mathrm{m}$ (Merck, Hungary) column coupled with a LiChrospher 100 RP-18 (Merck, Hungary) guard column and an injection volume of $5 \mu \mathrm{l}$. The isocratic mobile phase composition was water/methanol/acetonitrile 65/17.5/17.5 (v/ $v / v$ ), and the flow rate was maintained at $1 \mathrm{ml} / \mathrm{min}$, while the column temperature was $40{ }^{\circ} \mathrm{C}$. For the quantification of $\mathrm{AFB}_{1}$, the linear calibration curve was used in a concentration range of 6.25 to $100 \mathrm{ng} / \mathrm{ml}$ and the equation of resulted calibration curve was $\mathrm{y}=4056.2 \mathrm{x}-7321.2\left(R^{2}=0.9994\right)$.

\section{Cytotoxicity, genotoxicity, and immunomodulation of $\mathrm{AFB}_{1}$ vs Aspergilli section Flavi extracts}

\section{Cell cultures}

Human lung adenocarcinoma cells A549 and human leukemia monocytes THP-1 (European Collection of Cell Cultures, Salisbury, UK) were grown in $75 \mathrm{~cm}^{2}$ flasks in RPMI supplemented with $2 \mathrm{mmol} / 1$ glutamine, $10 \%$ heat-inactivated FBS, penicillin $(100 \mathrm{IU} / \mathrm{ml} ; 1 \mathrm{IU} 67.7 \mu \mathrm{g} / \mathrm{ml})$, and streptomycin $(100 \mu \mathrm{g} / \mathrm{ml})$. Cultures were maintained in a moisturized atmosphere with $5 \% \mathrm{CO}_{2}$ at $37{ }^{\circ} \mathrm{C}$ and $95 \%$ relative humidity.

\section{Preparation of tested compounds}

A stock solution of $\mathrm{AFB}_{1}(0.01 \mathrm{~mol} / \mathrm{l})$ was prepared in $\mathrm{DMSO} / 70 \%$ ethanol mixture 80/20 $v / v$. Weighed dried fungal extracts were dissolved in $100 \%$ DMSO. The final concentrations of $\mathrm{AFB}_{1}$ and fungal extracts as well as DMSO/ethanol used in the treatments of cells were obtained by dilution with the culture medium. The highest concentration of fungal extract applied as treatment was limited by the content of DMSO (up to $1 \%$ ) that showed no significant effect on cell viability. Mass concentrations of fungal extracts used in MTT assay ranged from 0.05 to $0.6 \mathrm{mg} / \mathrm{ml}$, while the corresponding content of $\mathrm{AFB}_{1}$ in the extract of toxin-producing $A$. flavus was 0.75 to $4.5 \mu \mathrm{mol} / \mathrm{l}$. Concentrations of the extracts used in other assays were selected according to the results of MTT and corresponded to subcytotoxic concentrations.

\section{MTT proliferation assay}

Viability of A549 cells and macrophage-like THP-1 cells was estimated using MTT assay, as described previously (Jakšić Despot et al. 2016). The differentiation of THP-1 cells into macrophages was performed using PMA (20 nm/well). The A549 ( $10^{4}$ cells/well) and macrophage-like THP-1 cells $(5 \times$ $10^{4}$ cells/well) were grown in a 96-well flat-bottom microplate in RPMI 1640 medium supplemented with $10 \%$ of FBS. Upon $24 \mathrm{~h}$ treatment with $\mathrm{AFB}_{1}(0.1$ to $100 \mu \mathrm{mol} / \mathrm{l})$ or with Aspergilli extracts $(0.05$ to $0.6 \mathrm{mg} / \mathrm{ml})$ of $\mathrm{AFB}_{1}$-producing and non-producing isolates, the concentration that inhibits growth in $50 \%$ of cells $\left(\mathrm{IC}_{50}\right)$ was determined. Following treatment, the medium was removed and $100 \mu \mathrm{l}$ of MTTtetrazolium salt reagent diluted in RPMI 1640 medium without FBS $(0.5 \mathrm{mg} / \mathrm{ml})$ was added $(\mathrm{V}=100 \mu \mathrm{l}$ per each well). After $3 \mathrm{~h}$ of incubation, the medium was replaced with $100 \mu \mathrm{l}$ of DMSO to dissolve formazan (product of metabolised MTT reagent), and cells were incubated at room temperature on a rotary shaker for $15 \mathrm{~min}$. The absorbance was measured using a microplate reader (Labsystem iEMS, type 1404) at a wavelength of $540 \mathrm{~nm}$. All tests were performed in five replicates, and results were expressed as percentage of control.

\section{Alkaline comet assay}

The extent of primary DNA damage produced after $24 \mathrm{~h}$ treatment with $\mathrm{AFB}_{1}$ and Aspergilli extracts was assessed in A549 cells using the alkaline comet assay. A standard protocol, proposed by Singh et al. (1988), with minor modifications was used. Before treatment, A549 cells were seeded in 6-well plates $\left(3 \times 10^{5}\right.$ cells per well) in RPMI 1640 medium 
supplemented with $10 \%$ of FBS. After $24 \mathrm{~h}$ of growth, the cell medium was discarded and cells were treated with $\mathrm{AFB}_{1}$ (at 1 and $10 \mu \mathrm{M}$ ), Aspergilli extracts (at 0.05 and $0.1 \mathrm{mg} / \mathrm{ml}$ for non-producing and 0.1 and $0.2 \mathrm{mg} / \mathrm{ml}$ for $\mathrm{AFB}_{1}$-producing isolate). Control cell cultures were grown in parallel (with and without $0.1 \% \mathrm{DMSO} /$ ethanol) for $24 \mathrm{~h}$. After $24 \mathrm{~h}$ of treatment, the cells were washed with $1 \mathrm{ml}$ cold PBS, scraped with rubber, and resuspended in $300 \mu \mathrm{l}$ of PBS. Aliquots $(\mathrm{V}=$ $20 \mu \mathrm{l})$ of this suspension were used to prepare slides for the comet assay. Briefly, cell samples were mixed with $100 \mu \mathrm{l}$ 0.5\% LMP agarose (in Ca- and Mg-free PBS) and spread onto fully frosted slides, previously pre-coated with $1 \%$ and $0.6 \%$ NMP agarose. The microgels were allowed to solidify on ice for $10 \mathrm{~min}$. Then, the slides were subjected to lysis at $4{ }^{\circ} \mathrm{C}$ in a buffer containing $2.5 \mathrm{~mol} / 1 \mathrm{NaCl}, 100 \mathrm{mmol} / 1 \mathrm{Na}_{2}$ EDTA, $10 \mathrm{mmol} / 1$ Tris ( $\mathrm{pH} \mathrm{10}$ ), supplemented with $1 \%$ Triton-X 100. The lysis step lasted for $1 \mathrm{~h}$ and was followed by denaturation in alkaline buffer $(10 \mathrm{mmol} / \mathrm{l} \mathrm{NaOH}, 200 \mathrm{mmol} / \mathrm{l}$ $\mathrm{Na}_{2}$ EDTA, pH 13), for $20 \mathrm{~min}$. Electrophoresis lasted for $20 \mathrm{~min}$ in the same buffer at $25 \mathrm{~V}$ and $300 \mathrm{~mA}$. Microgels were, then, neutralised with three changes of $0.4 \mathrm{~mol} / 1$ Tris/ $\mathrm{HCl}$ buffer ( $\mathrm{pH} 7.5$ ), for 5 min each. The slides were kept in a humid atmosphere in a dark box at $4{ }^{\circ} \mathrm{C}$ until further analysis. Before image analysis, DNA was stained for $10 \mathrm{~min}$ with ethidium bromide $(20 \mu \mathrm{g} / \mathrm{ml})$. Slides were scored using an image analysis system (Comet assay IV, InstemPerceptive Instruments Ltd., UK) connected to a fluorescence microscope (Olympus, Japan). All of the experiments were performed in duplicate, and, in each experiment, images of 200 randomly selected nucleoids (100 nucleoids from each of the two replicate slides) were measured. Only comets with a defined head were scored. As indicators of DNA damage, tail length (presented in micrometres) and tail intensity (i.e., percentage of DNA in the comet tail) were selected (Collins 2004).

\section{Determination of cytokine levels}

To establish cytokine levels after $24 \mathrm{~h}$ treatment with AFB1 and Aspergilli extracts, THP-1 cells were selected as an appropriate cell model. Cells were first seeded on 24-well cell culture plates $\left(1 \times 10^{6}\right.$ cells per well $)$ in RPMI 1640 medium supplemented with $10 \%$ of FBS and differentiated into macrophages for $24 \mathrm{~h}$ with addition of $40 \mathrm{nmol} / \mathrm{L} \mathrm{LM}$ PMA for $24 \mathrm{~h}$. After that, the medium was discarded, and cells were treated with $\mathrm{AFB}_{1}$ (at 1 and $10 \mu \mathrm{mol} / \mathrm{LM}$ ) and Aspergilli extracts (at 0.05 and $0.1 \mathrm{mg} / \mathrm{ml}$ for non-producing and 0.1 and $0.2 \mathrm{mg} / \mathrm{ml}$ for $\mathrm{AFB}_{1}$-producing isolate) for $24 \mathrm{~h}$. Control cell cultures were grown in parallel in RPMI 1640 medium supplemented with $10 \%$ of FBS (with and without $0.1 \%$ DMSO/ethanol) for $24 \mathrm{~h}$. Following treatment, the cell medium was harvested and frozen at $-80{ }^{\circ} \mathrm{C}$ until analysis. Concentrations of TNF- $\alpha$, IL-1 $\beta$, IL-6, IL-8, and IL-17 were determined in harvested cell medium by DuoSet ELISA kits (R\&D Systems, Minneapolis, USA) according to instructions provided by the manufacturer and as described elsewhere (Hulina et al. 2018). Cytokine concentrations were calculated from measured optical densities determined at $450 \mathrm{~nm}$, using a microplate reader (En Vision ${ }^{\circledR}$ Multilabel Plate Reader, Perkin Elmer) and by standard calibration curves, and results of the three replicates were expressed as percentage of control.

\section{Statistics}

Data obtained using the MTT test, comet assay, and cytokine concentration were first evaluated using descriptive statistics. The results were presented as mean \pm standard error of mean (SEM). Normality of data distribution was tested by Kolmogorov-Smirnov test; one-way ANOVA was applied for normally distributed data (MTT test and cytokine concentrations) followed by Sidak's post-test, while for non-normally distributed data (comet assay), Kruskal-Wallis test was applied followed by Dunn's multiple-comparison test. A value of $P<0.05$ was considered statistically significant for all calculations. To obtain the $\mathrm{IC}_{50}$ from the results of the MTT assay, non-linear dose-response fitting was applied using the equation $\mathrm{y}=\mathrm{A} 1+(\mathrm{A} 2-\mathrm{A} 1) /\left(1+10^{\wedge}((\operatorname{LOGx} 0-\mathrm{x}) * \mathrm{p})\right)$.

\section{Results and discussion}

\section{Occurrence of aflatoxigenic Aspergilli section Flavi in air samples}

The abundance of airborne Aspergillus species section Flavi in the occupational environment (GM) in contrast to inhabited urban homes (AP) and urban home basements (BS) as well as outdoor air (ODA) in the six periods of sampling is presented in Table 2. Only in GM were these Aspergilli present throughout the whole year, comprising $1-12 \%$ of total viable airborne fungi, with mean absolute concentrations approximately 100 to 2000 times higher than in other indoor, as well as outdoor locations. In the GM, the mean absolute concentrations of Aspergilli were highest in March and September (about $2000 \mathrm{cfu} / \mathrm{m}^{3}$ ), with a maximum of $2 \times 10^{4} \mathrm{cfu} / \mathrm{m}^{3}$ in September. Looking at the estimated concentrations (probable viable number), the airborne Aspergilli section Flavi were present at concentrations between $1.7 \times 10^{3} \mathrm{cfu} / \mathrm{m}^{3}$ (January) and $1.3 \times 10^{4} \mathrm{cfu} / \mathrm{m}^{3}$ (March) from January to September and dropped below $1000 \mathrm{cfu} / \mathrm{m}^{3}$ only in November. Comparing the results of the present study with our previous reports, the Aspergilli section Flavi occurred in significantly higher mean absolute concentrations in the GM $\left(405-2035 \mathrm{cfu} / \mathrm{m}^{3}\right)$ than both Aspergilli from the subclade Versicolores (6.5-44 cfu/ $\left.\mathrm{m}^{3}\right)$ and Aspergilli section Nigri (20-240 $\left.\mathrm{cfu} / \mathrm{m}^{3}\right)($ Jakšić Despot et al. 2016; Jakšić et al. 2018). Mean concentrations 
of viable Aspergilli section Flavi were also much higher than those reported in poultry farms, soybean and cotton mills, and the food industry $\left(17-137.6 \mathrm{cfu} / \mathrm{m}^{3}\right)$ in India, Italy, and Egypt (Sharma et al. 2010; Abdel Hameed et al. 2012; Cafarchia et al. 2014). Maximum values of statistically estimated concentrations of Aspergilli section Flavi obtained in July $(1.9 \times$ $\left.10^{5} \mathrm{cfu} / \mathrm{m}^{3}\right)$ and $\left(1.3 \times 10^{6} \mathrm{cfu} / \mathrm{m}^{3}\right)$ were $10-100$-fold higher than concentrations of airborne fungi $\left(>10^{4} \mathrm{cfu} / \mathrm{m}^{3}\right)$ considered as a health hazard in non-sensitized subjects (Oppliger et al. 2005). Contrary to the GM, Aspergilli section Flavi were rarely present or were in low concentrations (maximum $20 \mathrm{cfu} / \mathrm{m}^{3}$ ) in urban apartments and basements (AP and BS) and outdoors which is in agreement with recently conducted studies in homes of low-income areas in Syracuse (NY, USA) as well as in homes of hematologic patients in Germany (Crawford et al. 2015; Schweer et al. 2016). In most periods, these Aspergilli comprised between 0.1 and $0.2 \%$ of total viable airborne fungi recovered from AP, BS, and ODA.

Based on $C a M$ gene region sequencing, among a total of 67 Aspergilli section Flavi isolates, 65 were identified as A. flavus and 2 as A. parasiticus (Table 3) (data on A. parasiticus are not shown; results were published in Baranyi et al. 2015). The majority of A. flavus strains (89\%) were recovered from the GM. Among these strains, 76\% produced $\mathrm{AFB}_{1}$; the highest amounts of $\mathrm{AFB}_{1}(10-30 \mu \mathrm{g} / \mathrm{ml})$ were produced by strains isolated in March and November. For five strains of A. flavus, isolated from the GM environment, production of low amounts of $\mathrm{AFB}_{2}(0.03 \pm$ $0.02 \mu \mathrm{g} / \mathrm{ml})$ was detected, in addition to $\mathrm{AFB}_{1}(13.4 \pm$ $9.8 \mu \mathrm{g} / \mathrm{ml})$. These five strains represented $10 \%$ of all A. flavus isolates from the GM environment. The production of $\mathrm{AFB}_{1}$ and $\mathrm{AFB}_{2}$ correlated with genes detected for the transcriptional regulator of aflatoxin biosynthesis (aflR), norsolorinic acid reductase (norA), and O-methyltransferase gene (omtA); 15 strains were positive for two or all three genes for aflatoxin biosynthesis, but the amounts of the toxin were below the LOD. Several earlier studies have suggested the significance of respiratory exposure to A. flavus in biowastehandling facilities (up to $10^{5} \mathrm{cfu} / \mathrm{m}^{3}$ ) and $\mathrm{AFB}_{1}$ in grain dust ranging from 0.04 to $107 \mathrm{ng} / \mathrm{m}^{3}$ (Fischer et al. 2000a,b; Fischer and Dott 2003). Hardin et al. (2009) reviewed the significance of exposure to airborne fungi and mycotoxins in light of concentration of no toxicologic concern-CoNTC $\left(30 \mathrm{ng} / \mathrm{m}^{3}\right)$, which showed that in occupational environments, such as grain, handling the concentration of $\mathrm{AFB}_{1}$ in the facilities can exceed the CoNTC. Recently, in poultry farms in Portugal, A. flavus was found in three of seven poultry units, and this Aspergilli was the third most frequently found fungal species among indoor airborne fungi (Viegas et al. 2012). In the same study, the presence of aflatoxigenic strains was only confirmed in an outdoor air sample from one of the poultry units but direct evidence of the poultry workers' professional exposure to $\mathrm{AFB}_{1}$ was found in $58 \%$ of positive serum 
Table $3 \quad \mathrm{AFB}_{1}$-producing abilities of indoor A. flavus isolates from different sampling periods and locations

\begin{tabular}{|c|c|c|c|c|c|c|}
\hline Month of collection & Location & Isolate ID $^{\mathrm{a}}$ & $a f l R$ & norA & omtA & $\mathrm{AFB}_{1}(\mathrm{ng} / \mathrm{ml})$ \\
\hline \multirow[t]{4}{*}{ January } & \multirow[t]{4}{*}{ GM } & AF10527 I. & + & + & + & 4.9 \\
\hline & & AF10529 I. & + & + & + & 4.3 \\
\hline & & AF10523 I. & + & + & + & 4.1 \\
\hline & & AF10525 I. & + & + & + & 4.4 \\
\hline \multirow[t]{5}{*}{ March } & \multirow[t]{5}{*}{ GM } & AF10869B III. & + & + & + & $<\mathrm{LOD}$ \\
\hline & & AF10873 III. & + & - & - & $<$ LOD \\
\hline & & AF10868A III. & + & + & + & 4.7 \\
\hline & & AF10868B III. & + & + & + & $12,000.0$ \\
\hline & & AF10869A III. & + & + & + & 4.8 \\
\hline \multirow[t]{8}{*}{ May } & \multirow[t]{7}{*}{ GM } & AF10923A V. & + & + & + & 8.5 \\
\hline & & AF10926A V. & + & + & + & 5.6 \\
\hline & & AF10926B V. & + & + & + & 11.0 \\
\hline & & AF10923B V. & + & + & + & 4.6 \\
\hline & & AF10925B V. & + & + & + & 11.5 \\
\hline & & AF10927A V. & + & + & + & 4.3 \\
\hline & & AF10930B V. & + & - & - & $<$ LOD \\
\hline & BS & AF10959B V. & + & + & + & 5.0 \\
\hline \multirow[t]{19}{*}{ July } & \multirow[t]{18}{*}{ GM } & AF10989B VII. & + & + & + & 4.6 \\
\hline & & AF10992B VII. & + & + & + & 4.9 \\
\hline & & AF10993A VII. & + & + & + & $<$ LOD \\
\hline & & AF10993B VII. & + & + & + & 5.6 \\
\hline & & AF10994A VII. & + & + & + & 5.0 \\
\hline & & AF10995A VII. & + & + & + & 4.4 \\
\hline & & AF10997A VII. & + & + & + & 4.3 \\
\hline & & AF10988A VII. & + & + & + & 4.9 \\
\hline & & AF10988B VII. & + & + & + & 4.4 \\
\hline & & AF10989A VII. & + & + & + & $<\mathrm{LOD}$ \\
\hline & & AF10990B VII. & + & + & + & $<\mathrm{LOD}$ \\
\hline & & AF10991A VII. & + & + & + & 4.1 \\
\hline & & AF10992A VII. & + & + & + & $<\mathrm{LOD}$ \\
\hline & & AF10994B VII. & + & + & + & 5.0 \\
\hline & & AF10996A VII. & + & + & + & 204.0 \\
\hline & & AF10996B VII. & + & + & + & $<\mathrm{LOD}$ \\
\hline & & AF10997B VII. & + & + & + & 5.5 \\
\hline & & AF11012B VII. & + & + & + & 4.6 \\
\hline & AP & AF11008B VII. & + & + & + & $<\mathrm{LOD}$ \\
\hline \multirow[t]{13}{*}{ September } & \multirow[t]{13}{*}{ GM } & AF11045A IX. & + & + & + & 15.6 \\
\hline & & AF11046A IX. & + & + & + & $<$ LOD \\
\hline & & AF11048B IX. & + & + & + & 4.1 \\
\hline & & AF11050A IX. & + & + & + & 4.2 \\
\hline & & AF11149B IX. & - & - & - & - \\
\hline & & AF11046B IX. & + & + & + & $<\mathrm{LOD}$ \\
\hline & & AF11047B IX. & + & + & + & $<$ LOD \\
\hline & & AF11049A IX. & + & + & + & 4.71 \\
\hline & & AF11049B IX. & + & + & + & 657.0 \\
\hline & & AF11050B IX. & + & - & + & 4.3 \\
\hline & & AF11051A IX. & + & + & + & 6.2 \\
\hline & & AF11053A IX. & + & + & + & 5.9 \\
\hline & & AF11054A IX. & + & + & + & 4.7 \\
\hline
\end{tabular}


Table 3 (continued)

\begin{tabular}{|c|c|c|c|c|c|c|}
\hline Month of collection & Location & Isolate $\mathrm{ID}^{\mathrm{a}}$ & aflR & norA & omtA & $\mathrm{AFB}_{1}(\mathrm{ng} / \mathrm{ml})$ \\
\hline \multirow[t]{16}{*}{ November } & \multirow[t]{11}{*}{ GM } & AF11110A XI. & + & + & + & $11,000.0$ \\
\hline & & AF11112A XI. & + & + & + & 5.0 \\
\hline & & AF11113B XI. & + & + & + & 4.5 \\
\hline & & AF11117B XI. & + & + & + & $31,000.0$ \\
\hline & & AF11118A XI. & + & + & + & 4.4 \\
\hline & & AF11119A2 XI. & + & + & + & $11,000.0$ \\
\hline & & AF11119B XI. & + & + & + & 5.5 \\
\hline & & AF11110B XI. & + & + & - & $<\mathrm{LOD}$ \\
\hline & & AF11111B XI. & + & - & + & $<\mathrm{LOD}$ \\
\hline & & AF11116A XI. & + & + & + & 5.0 \\
\hline & & AF11119A1 XI. & + & + & + & $16,000.0$ \\
\hline & \multirow[t]{3}{*}{ BS } & AF11144B XI. & + & + & + & $<\mathrm{LOD}$ \\
\hline & & AF11140A XI. & + & + & + & 5.9 \\
\hline & & AF11140B XI. & + & + & + & 4.7 \\
\hline & \multirow[t]{2}{*}{ ODA } & AF11146B XI. & + & + & + & 4.5 \\
\hline & & AF11148A XI. & + & + & + & 6.1 \\
\hline
\end{tabular}

${ }^{a}$ Isolate ID, isolates of A. flavus are deposited under their designated ID in the microbial collection (MFBF) at the Department of Microbiology Faculty of Pharmacy and Biochemistry, University of Zagreb

GM, grain mill; AP, apartment; BS, basement; ODA, outdoor air

samples (mean $2 \mathrm{ng} / \mathrm{ml}$ ) in contrast to the $\mathrm{AFB}_{1}$-negative serum sampled from control individuals. On the other hand, in living environments, $\mathrm{AFB}_{1}$ does not seem to be relevant since its formation on building materials during fungal growth has not been detected (Rao 2016; Ren 1999). Our results suggest that a serious threat to human health due to exposure to airborne A. flavus could come only in occupational environments, such as grain mill facilities, but not from exposure in urban apartments and basements.

\section{Cytotoxicity of $\mathrm{AFB}_{1}$ vs $A$. flavus extracts}

The cytotoxic potential of Aspergilli extracts and $\mathrm{AFB}_{1}$ applied alone on A549 cells and THP-1 macrophage-like cells is presented in Table 4 and Fig. 1. Although $\mathrm{AFB}_{1}$ alone significantly reduced the viability of both A549 and THP-1 macrophage-like cells at concentrations up to $100 \mu \mathrm{mol} / \mathrm{l}$, the reduction did not fall below $50 \%$ and the $\mathrm{IC}_{50}$ was not calculated. Our results are consistent with previous studies on A549 cells and human bronchiolar epithelium BEAS-2B cells (Palanee et al. 2001; Vleet et al. 2002; McKean et al. 2006). Van Veelt et al. (2002) showed that CYP $1 \mathrm{~A} 2$ and 3A4 enzymes are responsible for the bioactivation of $\mathrm{AFB}_{1}$ into metabolites $\left(\mathrm{AFB}_{1} 8\right.$,9-epoxide and aflatoxin $\left.\mathrm{Q}_{1}\right)$ that evoked cytotoxicity in CYP-transfected cells of the bronchiolar epithelium (BCMV1A2 and B3A4). On the contrary, BEAS-2B and A549 have limited CYP activity, which was in agreement with their CYP gene expression profile (Garcia-Canton et al. 2013) and may explain the weak cytotoxicity of $\mathrm{AFB}_{1}$ obtained in both A549 and THP-1 macrophage-like cells.

The extract of $\mathrm{AFB}_{1}$-producing A. flavus induced a significant drop in the viability of A549 cells, while the nonproducing strain was not cytotoxic to them. THP-1 macrophage-like cells were more sensitive to both extracts, but the $\mathrm{AFB}_{1}$-producing strain exerted stronger cytotoxicity with $\mathrm{IC}_{50}$ $\left(0.37 \pm 0.024 \mathrm{mg} / \mathrm{ml}\right.$; the corresponding $\mathrm{AFB}_{1}$ concentration is $2.78 \pm 0.18 \mu \mathrm{mol} / 1 \mathrm{AFB}_{1}$ ). Thus, we may suggest that $\mathrm{AFB}_{1}$ contributed to the A. flavus extract cytotoxicity but only in THP-1 macrophage-like cells. Piecková and Wilkins (2004) showed that endo- and exometabolite extracts of dust-borne A. flavus were able to stop chicken tracheal cilia beating after the first $24 \mathrm{~h}$ of activity. Recently, it was shown that exposure
Table 4 The calculated $\mathrm{IC}_{50}$ of $\mathrm{AFB}_{1}$ negative and positive A. flavus extracts $(0.05$ $0.6 \mathrm{mg} / \mathrm{ml}$ ) in A549 and THP-1 macrophage-like cell lines using non-linear curve fitting (0.9914)

\begin{tabular}{lll}
\hline Treatment & $\begin{array}{l}\mathrm{IC}_{50}(\mathrm{~A} 549) \\
(\mathrm{x} \pm \mathrm{SEM})\end{array}$ & $\begin{array}{l}\mathrm{IC}_{50}(\mathrm{THP}-1) \\
(\mathrm{x} \pm \mathrm{SEM})\end{array}$ \\
\hline A. flavus $\left(\mathrm{AFB}_{1}\right.$-negative) & $>0.6 \mathrm{mg} / \mathrm{ml}$ & $>0.4 \mathrm{mg} / \mathrm{ml}$ \\
A. flavus $\left(\mathrm{AFB}_{1}\right.$-positive) & $>0.4 \mathrm{mg} / \mathrm{ml}$ & $0.37 \pm 0.024 \mathrm{mg} / \mathrm{ml}\left(\mathrm{AFB}_{1} 2.78 \mu \mathrm{M}\right)$ \\
$\mathrm{AFB}_{1}$ & $>100 \mu \mathrm{M}$ & $>100 \mu \mathrm{M}$ \\
\hline
\end{tabular}



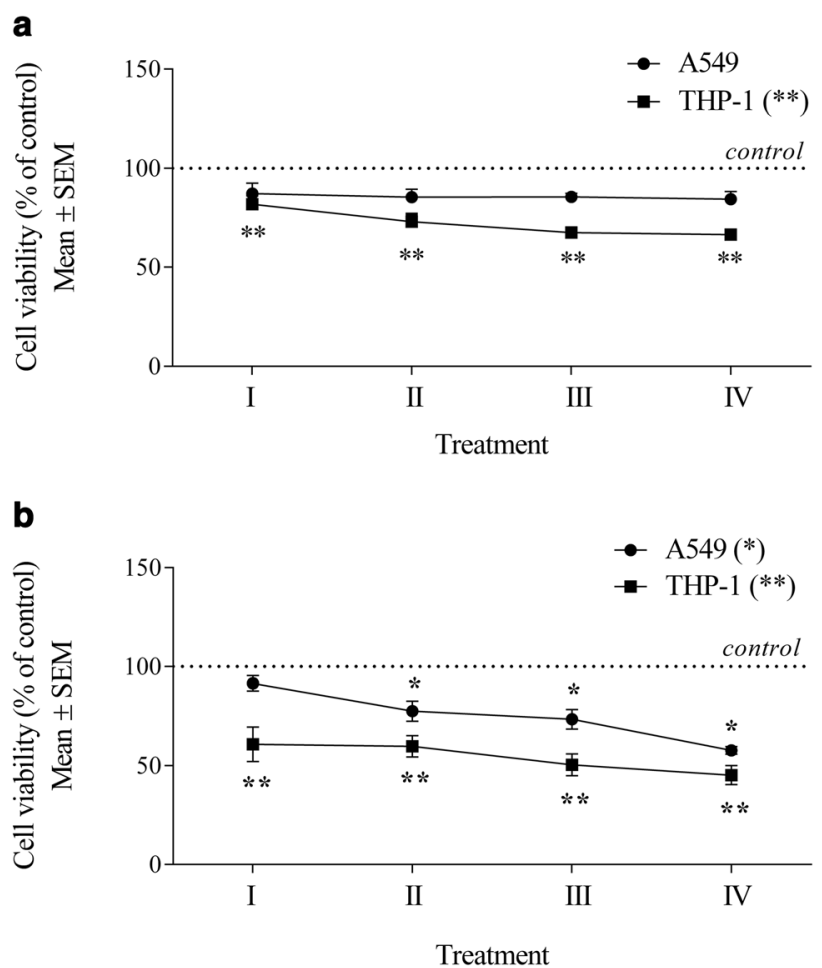

Fig. 1 Survival of THP-1 macrophage-like cells and A549 cells after $24 \mathrm{~h}$ of the treatment with the extract prepared from $\mathrm{AFB}_{1}$-negative (a) and $\mathrm{AFB}_{1}$-positive (b) isolate of A. flavus and single $\mathrm{AFB}_{1}$ (c). Mass concentrations of fungal extracts prepared from $\mathrm{AFB}_{1}$-negative isolate of A. flavus were I 0.05 , II 0.1 , III 0.25 , and IV $0.4 \mathrm{mg} / \mathrm{ml}$ (a), in the extract of toxin-producing A. flavus I 0.1 , II 0.2 , III 0.4 , and IV $0.6 \mathrm{mg} / \mathrm{ml}$,

of primary human sinonasal and bronchial cell cultures to aflatoxins $(0.1$ to $10 \mu \mathrm{mol} / \mathrm{l})$ as well as to conditioned media from $A$. flavus reduced the ciliary beat frequency. The effect was blocked by an anti-aflatoxin antibody suggesting that the aflatoxin was responsible for the reduction of ciliary beat frequency (Lee et al. 2016). The same study revealed that $\mathrm{AFB}_{2}$ activates protein kinase $\mathrm{C}$ in A549 cells, which has been linked to inflammation and apoptosis (Diaz-Meco and Moscat 2012; Zhao et al. 2012). Taken together, our results suggest that although $\mathrm{AFB}_{1}$ alone exerted weak cytotoxic properties in THP-1-like macrophages and A549 lung cells, it significantly contributes to the cytotoxicity of A. flavus extracts. Therefore, chronic exposure to aflatoxins in the mixture of $A$. flavus metabolites in an occupational environment may stimulate epithelial damage in airways accompanied by lowered macrophage viability contributing to the pathogenesis of respiratory diseases.

\section{Genotoxicity of $\mathrm{AFB}_{1}$ vs $A$. flavus extracts}

Genotoxic effects were evaluated in A549 cells using the alkaline comet assay (Fig. 2). $\mathrm{AFB}_{1}$ alone evoked significant concentration-dependent DNA damage measured as tail intensity but not in terms of tail length as compared to control.

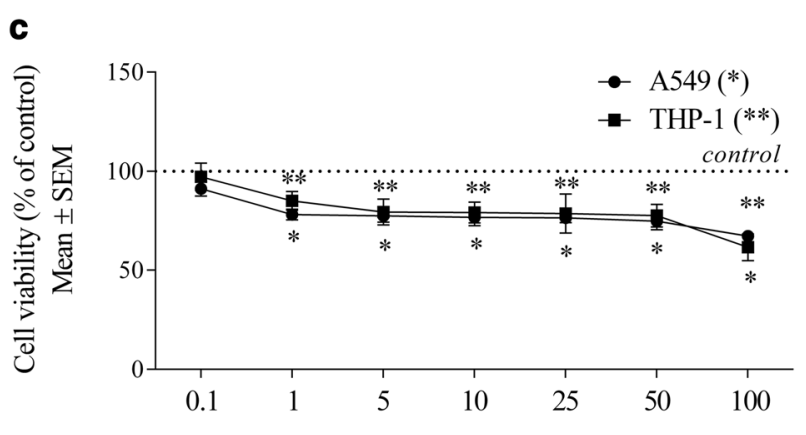

Concentration $\left(\mathrm{AFB}_{1}\right), \mu \mathrm{mol} / 1$

while the corresponding content of $\mathrm{AFB}_{1}$ was $0.75,1.5,3.0$, and $4.5 \mu \mathrm{mol} / 1,1-4$ respectively (b). Each data point represents the mean \pm SEM of cell viability ( $\%$ of control, control $=100 \%$ of cell viability). *, **Significantly different as compared to control in A549 and THP-1 macrophage like cells, respectively $(P<0.05)$

Contrary to $\mathrm{AFB}_{1}$, Aspergilli extracts provoked a significant concentration-dependent increase of tail length but not tail intensity. The difference in the responses at DNA level observed after the treatments could be explained by the intrinsic differences in the mechanisms behind DNA lesions. Without conducting additional experiments, we cannot establish the exact mechanism(s) responsible for the observed effects. However, as a comet's tail length is proportional to the number of relaxed DNA loops (Collins et al. 2008), it seems that treatment with Aspergilli extracts led to an increased number of relaxed DNA loops, but without a concomitant increase in the amount of DNA breaks. This could be, at least in part, associated with the chemical composition of the extract, which - besides $\mathrm{AFB}_{1}$ - contains other active compounds as well, which possess different potentials to damage DNA or even modulate the DNA damaging effects of $\mathrm{AFB}_{1}$ itself.

When discussing the significance of the comet assay parameters evaluated in this study, it has to be stressed that tail intensity has been deemed the most useful because as the level of damage increases so does the relative intensity of DNA staining in the tail, rather than tail length (Collins et al. 2008). Therefore, the significantly increased tail intensity we recorded at both of the tested concentrations represents an important piece of information regarding $\mathrm{AFB}_{1}$ genotoxicity, 


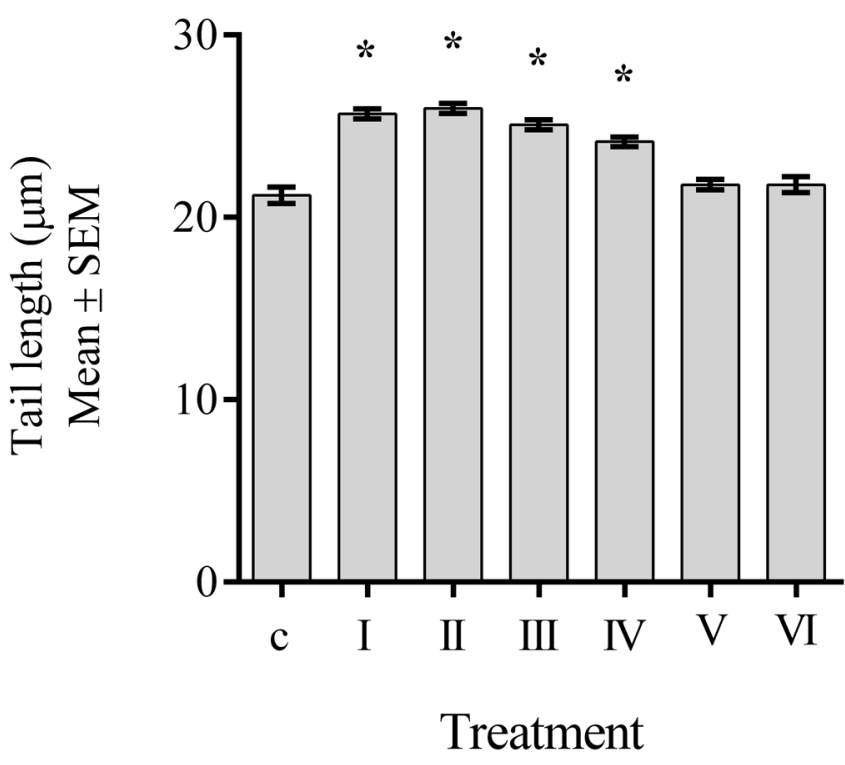

Fig. 2 Genotoxicity of $\mathrm{AFB}_{1}$-negative and $\mathrm{AFB}_{1}$-positive extracts of A. flavus isolates as well as $\mathrm{AFB}_{1}$ applied in subcytotoxic concentrations determined by alkaline comet assay as tail length and tail intensity in A549 cells. C control (0.1\% DMSO), $\mathrm{I} \mathrm{AFB}_{1}$-negative extract of A. flavus $0.05 \mathrm{mg} / \mathrm{ml}$, II $\mathrm{AFB}_{1}$-negative extract of $A$. flavus

which will be useful for planning future experiments with other cell types and exposure scenarios.

The underlying mechanism of $\mathrm{AFB}_{1}$ genotoxicity was previously studied in the liver in vivo as well as in liver cells and several human bronchial cell lines with good expression of CYP $1 \mathrm{~A} 2$ and $3 \mathrm{~A} 4$ enzymes responsible for $\mathrm{AFB}_{1}$ biotransformation into reactive $\mathrm{AFB}_{1}$ 8,9-epoxide that binds to DNA (reviewed in Marchese et al. 2018). An association between lung cancer development following $\mathrm{AFB}_{1}$ exposure was described in workers occupationally exposed to grain dust contaminated with this compound (Hayes et al. 1984). It was demonstrated that $\mathrm{AFB}_{1}$ exposure induced the production of a DNA binding metabolite (epoxide) by lung cytosols which was correlated with lipoxygenase and prostaglandin $\mathrm{H}$ synthase and increased human pulmonary susceptibility to $\mathrm{AFB}_{1}$ (Massey et al. 2000). Also, oxidative DNA damages in mouse lung cells were correlated to $\mathrm{AFB}_{1}$ genotoxicity, owing to the induction of 8-hydroxy-20-deoxyguanosine (8OHdG) formation (Guindon et al. 2008). Although A549 cells possess a limited expression of CYP enzymes (Garcia-Canton et al. 2013), our results suggest that it was sufficient to induce DNA damage upon exposure to low concentrations of $\mathrm{AFB}_{1}$. In our previous study, $\mathrm{AFB}_{1}$ (at $5 \mu \mathrm{mol} / \mathrm{l}$ ) also evoked significant DNA damage and mutagenic activity, as revealed by the alkaline comet assay, and led to micronuclei formation (Jakšić et al. 2012). Since both the $\mathrm{AFB}_{1}$-positive and the $\mathrm{AFB}_{1}$-negative Aspergilli extracts exerted similar genotoxic action in A549 cells, we may hypothesize that other metabolites present

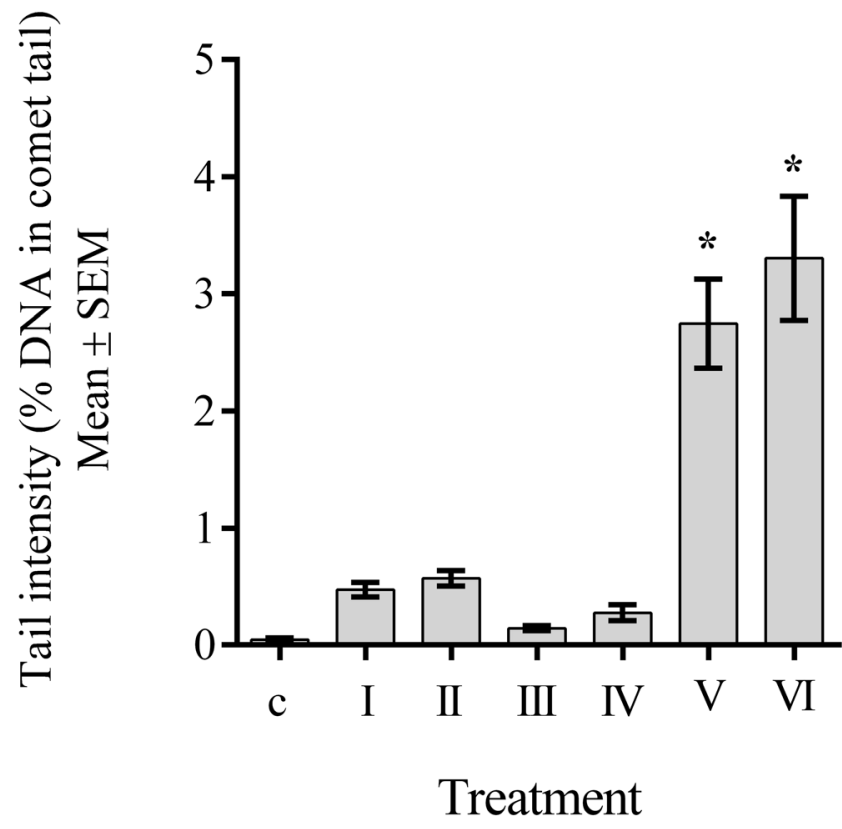

$0.1 \mathrm{mg} / \mathrm{ml}$, III $\mathrm{AFB}_{1}$-positive extract of A. flavus $0.1 \mathrm{mg} / \mathrm{ml}, \mathrm{IV} \mathrm{AFB}_{1^{-}}$ positive extract of $A$. flavus $0.2 \mathrm{mg} / \mathrm{ml}$, VAFB $1 \mu \mathrm{mol} / \mathrm{l}$, VI $\mathrm{AFB}_{1}$ $10 \mu \mathrm{mol} / \mathrm{l}$. The statistical significance of the treatment compared to control is marked with an asterisk $(*, P<0.05)$ above each histogram

in the extract might antagonise $\mathrm{AFB}_{1}$ 's genotoxic action in $\mathrm{AFB}_{1}$-producing strains.

\section{Immunomodulatory effects of $\mathrm{AFB}_{1}$ vs $A$. flavus extracts}

Many macrophage and epithelial cells produce cytokines and chemokines after challenges from various inflammatory stimuli. Thus, we explored the differences in the secretion of proinflammatory cytokines (TNF- $\alpha$, IL-1 $\beta$, IL-6, IL-8, IL-17) by THP-1 macrophage-like cells upon exposure to single $\mathrm{AFB}_{1}$ or Aspergilli extracts (Fig. 3). TNF- $\alpha$ is an endogenous pyrogen and immunoregulatory cytokine responsible for the production of IL-1, IL-6, and IL-8. Deficiency of TNF- $\alpha$ in experimental animals promoted cancer (Suganuma et al. 1999). TNF- $\alpha$ stimulates polymorphonuclear leukocytes to damage Aspergillus hyphae enhancing phagocytosis (Roilides et al. 2002). IL-1 $\beta$ is a potent pro-inflammatory cytokine secreted by macrophages and monocytes which has a stimulatory effect on CD4+ $\mathrm{T}$ cells promoting differentiation into the $\mathrm{T}$ helper cell. It has a beneficial role of mediating an immune response against pathogenic infiltration, but it can also promote the pathogenesis of tissue damage that leads to chronic inflammation (Eder 2009; Turner et al. 2014). Similarly to TNF, IL-6 is a pleiotropic cytokine showing both proinflammatory and anti-inflammatory activities, but, in chronic inflammation, it is rather pro-inflammatory. The synthesis of this cytokine is induced by IL-1 and TNF- $\alpha$ (Duque and 


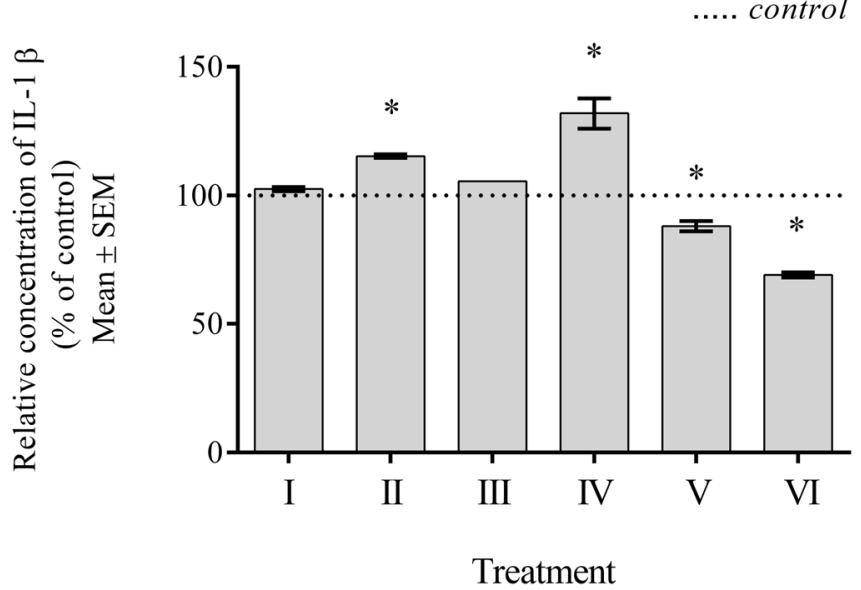

..... control
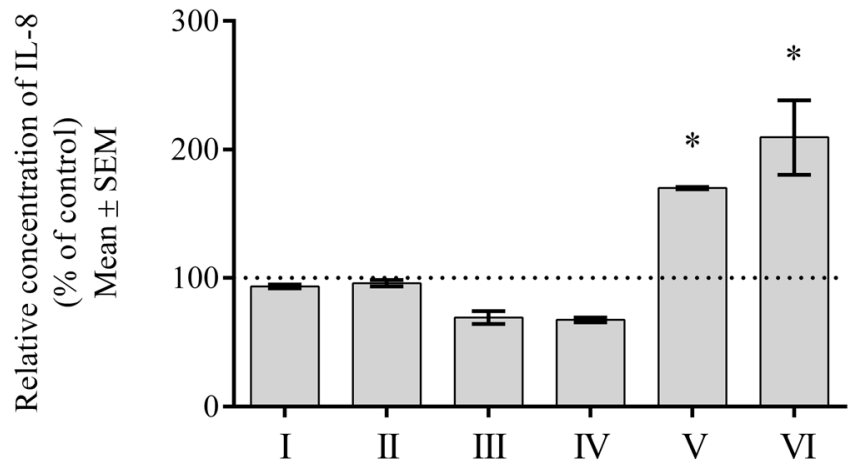

Treatment

..... control
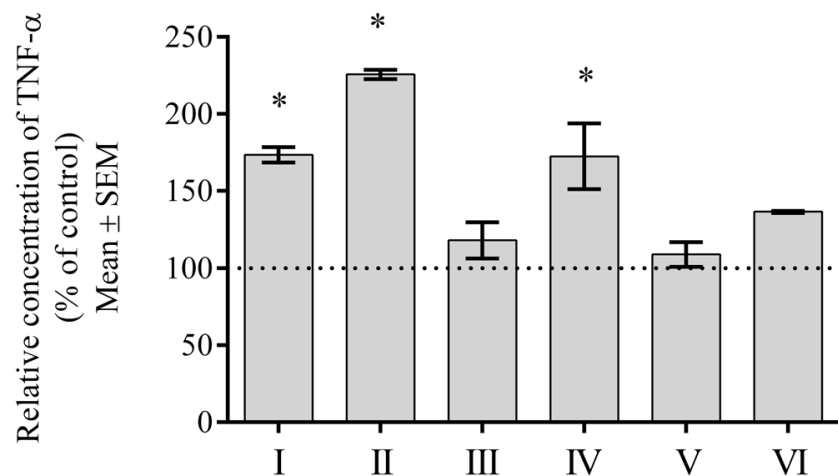

Treatment

Fig. 3 Relative concentration of cytokines measured in the supernatant of THP-1 macrophage-like cells upon treatment: $\mathrm{I} \mathrm{AFB}_{1}$-negative extract of

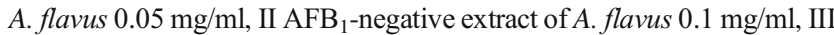

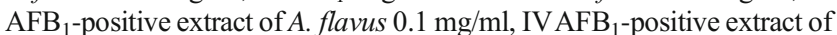

Descoteaux 2014). IL-8, also known as chemokine CXCL8, is a monocyte- and macrophage-derived cytokine that serves as a chemoattractant of neutrophils to the site of infection or injury and whose secretion from macrophages can be

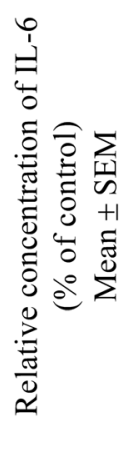

..... control

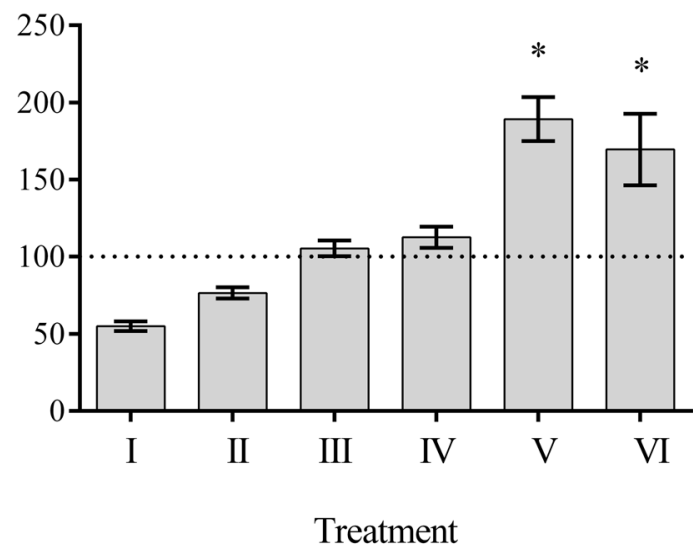

control
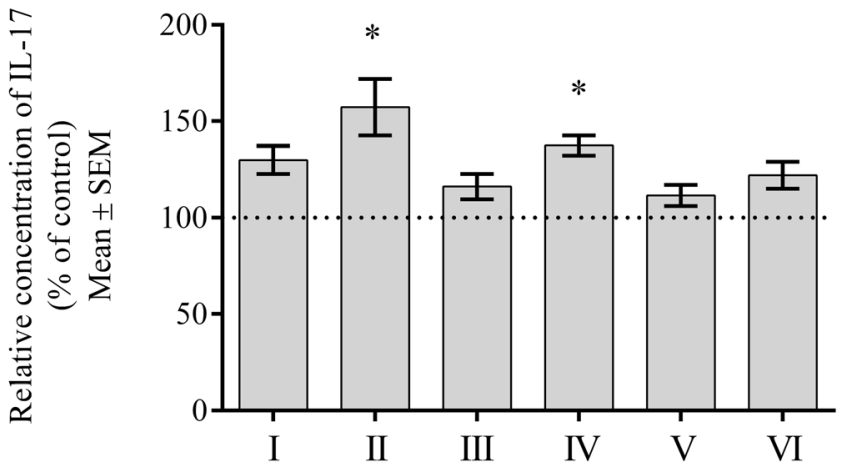

Treatment
A. flavus $0.2 \mathrm{mg} / \mathrm{ml}, \mathrm{VAFB}_{1} 1 \mu \mathrm{mol} / \mathrm{l}, \mathrm{VI} \mathrm{AFB}_{1} 10 \mu \mathrm{mol} / 1$. The statistical significance of the treatment compared to control $(0.1 \%$ DMSO) is marked with an asterisk $(*, P<0.05)$ above each histogram

stimulated with TNF- $\alpha$, IL- $1 \beta$, or a lipopolysaccharide (Carré et al. 1991). IL-17 is a pro-inflammatory cytokine that plays an essential role in the host's defense against microbial infections and is implicated in various inflammatory 
conditions, such as autoimmune diseases, metabolic disorders, and cancer (Gu et al. 2013).

$\mathrm{AFB}_{1}$ alone vs Aspergilli extracts showed differences in the immunomodulatory pattern. $\mathrm{AFB}_{1}$ has the most pronounced concentration-dependent effect on IL- 6 and IL-8 excretion. Although the release of TNF- $\alpha$ and IL-17 was also increased by $\mathrm{AFB}_{1}$ in a concentration-dependent manner, it was not significantly different from controls. Additionally, a difference in IL- $1 \beta$ release by THP-1 macrophage-like cells upon treatment with single $\mathrm{AFB}_{1}$ vs Aspergilli extract was also observed; $\mathrm{AFB}_{1}$ decreased IL- $1 \beta$ levels, while both Aspergilli extracts increased the release of this cytokine in a concentration-dependent manner. Several in vivo studies have also shown that $\mathrm{AFB}_{1}$ stimulates the expression of IL-6 (Hinton et al. 2003; Meissonnier et al. 2008; Qian et al. 2014; Abbès et al. 2016). The same in vivo studies suggested that secretion of TNF- $\alpha$ significantly depends on the administered dose of $\mathrm{AFB}_{1}$; e.g., a dose of $1.8 \mathrm{mg} / \mathrm{kg} \mathrm{AFB}{ }_{1}$ during four weeks of administration resulted in an increased expression of TNF- $\alpha$ (Meissonnier et al. 2008), while at a significantly lower dose $\left(80 \mu \mathrm{g} / \mathrm{kg}\right.$ ), $\mathrm{AFB}_{1}$ decreased TNF- $\alpha$ (Abbès et al. 2016). In primary alveolar pig macrophages, $\mathrm{AFB}_{1}(1-$ $100 \mathrm{ng} / \mathrm{ml}$ ) did not have an effect on the expression of both TNF- $\alpha$ and IL- $1 \beta$ but decreased phagocytosis efficiency (Liu et al. 2002). The inhibition of macrophage phagocytic activity was also established in vivo in a study on pigs which found that the inhalation of $16.8 \mu \mathrm{g} / \mathrm{kg}$ of $\mathrm{AFB}_{1}$ inhibited the phagocytic activity of alveolar macrophages without recovery of function two weeks after inhalation (Jakab et al. 1994). Similarly to our study, $\mathrm{AFB}_{1}$ evoked an increased expression of IL-8 mRNA in human lymphoblastoid Jurkat T-cells. The activation of an inflammatory response and over-active IL-8induced recruitment of neutrophils to specific tissues can result in extensive tissue damage (Luongo et al. 2014). As in our study, IL-17 levels increased as the dose increase of $\mathrm{AFB}_{1}$ in mice liver did, but no differences were detected between the treated and control groups (Ishikawa et al. 2017). Opposite to $\mathrm{AFB}_{1}$, both Aspergilli extracts provoked a significant increase of TNF- $\alpha$, IL-1 $\beta$, and IL-17 in THP-1 macrophage-like cells, while not inducing a release of IL- 6 and IL-8. The excretion of TNF- $\alpha$, IL- $1 \beta$, and IL- 17 was probably affected by the other metabolites in the extracts of A. flavus that could have acted in synergy with $\mathrm{AFB}_{1}$. At the same time, the metabolite mixtures in the extract could have had an antagonising activity on the induction of IL-6 and IL-8. Additionally, IL-17 appeared to play a central role in eosinophil extravasation from the blood into the lungs of mice upon intranasal exposure to A. fumigatus conidia (Murdock et al. 2012), which also contains metabolite mixture. Taken together, $\mathrm{AFB}_{1}$ elevated IL-6 and IL-8 while Aspergilli extracts increased IL- $1 \mathrm{~b}$, TNF-a, and IL-17 release in THP-1 macrophage-like cells suggesting that $\mathrm{AFB}_{1}$ alone and both $\mathrm{AFB}_{1}$-positive and $\mathrm{AFB}_{1}$-negative Aspergilli extracts could potentially impart adverse effects on innate immunity but with different mechanisms that could be influenced by the metabolite mixture composition in the extracts.

Considering the limitations of in vitro experiments, we may only suggest that chronic inhalatory exposure to $\mathrm{AFB}_{1}$ and/or other A. flavus metabolites in occupational environments can stimulate epithelial damage of airways accompanied by lowered macrophage viability but with a different underlying mechanism depending on the extrolite profile of the airborne A. flavus.

Acknowledgments This work was financially supported by the University of Zagreb (Grant No. 1126). This study forms part of the project GINOP-2.3.2-15-2016-00012, supported by the European Social Fund. This work was also supported by OTKA grant Nos. K115690 and K8407 as well as through András Szekeres, who received support through the new national excellence program of the Hungarian Ministry of Human Capacities.

\section{Compliance with ethical standards}

Conflicts of interest The authors declare that they have no conflict of interest.

Publisher's note Springer Nature remains neutral with regard to jurisdictional claims in published maps and institutional affiliations.

\section{References}

Abbès S, Ben Salah-Abbès J, Jebali R, Younes RB, Oueslati R (2016) Interaction of aflatoxin $\mathrm{B}_{1}$ and fumonisin $\mathrm{B}_{1}$ in mice causes immunotoxicity and oxidative stress: possible protective role using lactic acid bacteria. J Immunotoxicol 13:46-54. https://doi.org/10. 3109/1547691X.2014.997905

Abdel Hameed AA, Ayesh AM, Abdel Razik Mohamed M, Abdel Mawla H (2012) Fungi and some mycotoxins producing species in the air of soybean and cotton mills: a case study. Atmos Pollut Res 3: 126-131. https://doi.org/10.5094/APR.2012.012

Altschul S, Gish W, Miller W, Myers EW, Lipman DJ (1990) Basic local alignment search tool. J Mol Biol 215:403-410

Baranyi N, Jakšić Despot D, Palágyi A, Kiss N, Kocsubé S, Szekeres A, Kecskeméti A, Bencsik O, Vágvölgyi C, Šegvić Klarić M, Varga J (2015) Identification of Aspergillus species in Central Europe able to produce G-type aflatoxins. Acta Biol Hung 66:339-347. https://doi. org/10.1556/018.66.2015.3.9

Bennett JW, Klich M, Mycotoxins M (2003) Mycotoxins. Clin Microbiol Rev 16:497-516. https://doi.org/10.1128/CMR.16.3.497

Cafarchia C, Camarda A, Iatta R, Danesi P, Favuzzi V, Di Paola G, Pugliese N, Caroli A, Montagna MT, Otranto D (2014) Environmental contamination by Aspergillus spp. in laying hen farms and associated health risks for farm workers. J Med Microbiol 63:464 470. https://doi.org/10.1099/jmm.0.065946-0

Campbell-Platt G (1994) Fermented foods - a world perspective. Food Res Int 27:253-257. https://doi.org/10.1016/0963-9969(94)90093-0

Carré PC, Mortenson RL, King TE, Noble PW, Sable CL, Riches DW (1991) Increased expression of the interleukin- 8 gene by alveolar macrophages in idiopathic pulmonary fibrosis. A potential mechanism for the recruitment and activation of neutrophils in lung fibrosis. J Clin Invest 88:1802-1810. https://doi.org/10.1172/JCI115501 
Collins AR (2004) The comet assay for DNA damage and repair: principles, applications, and limitations. Mol Biotechnol 26:249-261. https://doi.org/10.1385/MB:26:3:249

Collins AR, Oscoz AA, Brunborg G, Gaivão I, Giovannelli L, Kruszewski M, Smith CC, Stetina R (2008) The comet assay: topical issues. Mutagenesis 23:143-151. https://doi.org/10.1093/ mutage/gem051

Crawford JA, Rosenbaum PF, Anagnost SE, Hunt A, Abraham JL (2015) Indicators of airborne fungal concentrations in urban homes: understanding the conditions that affect indoor fungal exposures. Sci Total Environ 517:113-124. https://doi.org/10.1016/j.scitotenv.2015.02. 060

Criseo G, Bagnara A, Bisignano G (2001) Differentiation of aflatoxinproducing and non-producing strains of Aspergillus favus group. Lett Appl Microbiol 33:291-295

Diaz-Meco MT, Moscat J (2012) The atypical PKCs in inflammation: NF-KB and beyond. Immunol Rev 246:154-167. https://doi.org/ 10.1111/j.1600-065X.2012.01093.x

Duque GA, Descoteaux A (2014) Macrophage cytokines: involvement in immunity and infectious diseases. Front Microbiol 5:1-12. https:// doi.org/10.3389/fimmu.2014.00491

Eder C (2009) Mechanisms of interleukin-1 b release. Immunobiology 214:543-553. https://doi.org/10.1016/j.imbio.2008.11.007

Fazekas B, Tar A, Kovács M (2005) Aflatoxin and ochratoxin A content of spices in Hungary. Food Addit Contam 22:856-863. https://doi. org/10.1080/02652030500198027

Fischer G, Dott W (2003) Relevance of airborne fungi and their secondary metabolites for environmental, occupational and indoor hygiene. Arch Microbiol 179:75-82. https://doi.org/10.1007/s00203-0020495-2

Fischer G, Müller T, Schwalbe R, Ostrowski R, Dott W (2000a) Exposure to airborne fungi, MVOC and mycotoxins in biowaste-handling facilities. Int J Hyg Environ Health 203:97-104. https://doi.org/10. 1078/S1438-4639(04)70014-0

Fischer G, Müller T, Schwalbe R, Ostrowski R, Dott W (2000b) Speciesspecific profiles of mycotoxins produced in cultures and associated with conidia of airborne fungi derived from biowaste. Int J Hyg Environ Health 203:105-116. https://doi.org/10.1078/S14384639(04)70015-2

Frisvad JC, Smedsgaard J, Samson RA, Larsen TO, Thrane U (2007) Fumonisin B production by Aspergillus niger. J Agric Food Chem 55(23):9727-9732

Garcia-Canton C, Minet E, Anadon A, Anadon A, Meredith C (2013) Metabolic characterization of cell systems used in in vitro toxicology testing: lung cell system BEAS-2B as a working example. Toxicol in Vitro 27:1719-1727. https://doi.org/10.1016/j.tiv.2013. 05.001

Geisen R (1996) Multiplex polymerase chain reaction for the detection of potential aflatoxin and sterigmatocystin producing fungi. Syst Appl Microbiol 19:388-392. https://doi.org/10.1016/S0723-2020(96) 80067-1

Godet M, Munaut F (2010) Molecular strategy for identification in Aspergillus section Flavi. FEMS Microbiol Lett 304:157-168. https://doi.org/10.1111/j.1574-6968.2009.01890.x

Gu C, Wu L, Li X (2013) IL-17 family: cytokines, receptors and signaling. Cytokine 64:389-399. https://doi.org/10.1016/j.asieco.2008. 09.006.EAST

Guindon KA, Foley JF, Maronpot RR, Massey TE (2008) Failure of catalase to protect against aflatoxin $\mathrm{B}_{1}$-induced mouse lung tumorigenicity. Toxicol Appl Pharmacol 227:179-183. https://doi.org/10. 1016/j.taap.2007.10.015

Hardin BD, Robbins CA, Fallah P, Kelman BJ (2009) The concentration of no toxicologic concern (CoNTC) and airborne mycotoxins. $\mathrm{J}$ Toxicol Environ Heal-Part A Curr Issues 72:585-598. https:// doi.org/10.1080/15287390802706389
Hayes RB, van Nieuwenhuize JP, Raatgever JW, ten Kate FJ (1984) Aflatoxin exposures in the industrial setting: an epidemiological study of mortality. Food Chem Toxicol 22:39-43. https://doi.org/ 10.1016/0278-6915(84)90050-4

Hedayati MT, Pasqualotto AC, Warn PA, Bowyer P, Denning DW (2007) Aspergillus flavus: human pathogen, allergen and mycotoxin producer. Microbiology 153:1677-1692. https://doi.org/10.1099/mic.0. 2007/007641-0

Hinton DM, Myers MJ, Raybourne RA, Francke-Carroll S, Sotomayor RE, Shaddock J, Warbritton A, Chou MW (2003) Immunotoxicity of aflatoxin B1 in rats: effects on lymphocytes and the inflammatory response in a chronic intermittent dosing study. Toxicol Sci 73:362377. https://doi.org/10.1093/toxsci/kfg074

Hong S-B, Go S-J, Shin H-D, Frisvad JC, Samson RA (2005) Polyphasic taxonomy of Aspergillus fumigatus and related species. Mycologia 97:1316-1329. https://doi.org/10.3852/mycologia.97.6.1316

Hulina A, Grdić Rajković M, Jakšić Despot D, Jelić D, Dojder A, Čepelak I, Rumora L (2018) Extracellular Hsp70 induces inflammation and modulates LPS/LTA-stimulated inflammatory response in THP-1 cells. Cell Stress Chaperones 23:373-384. https://doi.org/10. 1007/s12192-017-0847-0

Ishikawa AT, Hirooka EY, e Silva PLA, Bracarense APFRL, Flaiban KKMDC, Akagi CY, Kawamura O, Costa MCD, Itano EN (2017) Impact of a single oral acute dose of aflatoxin $\mathrm{B}_{1}$ on liver function/ cytokines and the lymphoproliferative response in C57BL/6 mice. Toxins 9:1-10. doi: https://doi.org/10.3390/toxins9110374

Jakab GJ, Hmieleski RR, Zarba A, Hemenway DR, Groopman JD (1994) Respiratory aflatoxicosis: a suppression of pulmonary and systemic host defenses in rats and mice. Toxicol Appl Pharmacol 125:198 205. https://doi.org/10.1006/TAAP.1994.1065

Jakšić Despot D, Šegvić Klarić M (2014) A year-round investigation of indoor airborne fungi in Croatia. Arh Hig Rada Toksikol 65:209218. https://doi.org/10.2478/10004-1254-65-2014-2483

Jakšić Despot D, Kocsubé S, Bencsik O, Kecskeméti A, Szekeres A, Jelić D, Kopjar N, Vágvölgyi C, Varga J, Šegvić Klarić M (2016) Species diversity and cytotoxic potency of airborne sterigmatocystinproducing Aspergilli from the section Versicolores. Sci Total Environ 562:296-304. https://doi.org/10.1016/j.scitotenv.2016.03. 183

Jakšić D, Puel O, Canlet C, Kopjar N, Kosalec I, Šegvić Klarić M (2012) Cytotoxicity and genotoxicity of versicolorins and 5methoxysterigmatocystin in A549 cells. Arch Toxicol 86:15831591. https://doi.org/10.1007/s00204-012-0871-x

Jakšić D, Kocsubé S, Bencsik O, Kecskeméti A, Szekeres A, Jelić D, Kopjar N, Vágvölgyi C, Varga J, Šegvić Klarić M (2018) Fumonisin production and toxic capacity in airborne black Aspergilli. Toxicol in Vitro 53:160-171. https://doi.org/10.1016/j.tiv.2018.08.006

Kelly JD, Eaton DL, Guengerich FP, Coulombe RA Jr (1997) Aflatoxin B1 activation in human lung. Toxicol Appl Pharmacol 144:88-95. https://doi.org/10.1006/taap.1997.8117

Lee RJ, Workman AD, Carey RM, B1 C, Rosen PL, Doghramji L, Adappa ND, Palmer JN, Kennedy DW, Cohen NA (2016) Fungal aflatoxins reduce respiratory mucosal ciliary function. Sci Rep 6:113. https://doi.org/10.1038/srep33221

Liu BH, Yu FY, Chan MH, Yang YL (2002) The effects of mycotoxins, fumonisin $\mathrm{B}_{1}$ and aflatoxin $\mathrm{B}_{1}$, on primary swine alveolar macrophages. Toxicol Appl Pharmacol 180:197-204. https://doi.org/10. 1006/taap.2002.9406

Luongo D, Russo R, Balestrieri A, Marzocco S, Bergamo P, Severino L (2014) In vitro study of $\mathrm{AFB}_{1}$ and $\mathrm{AFM}_{1}$ effects on human lymphoblastoid Jurkat T-cell model. J Immunotoxicol 11:353-358. https://doi.org/10.3109/1547691X.2013.848250

Manikandan P, Varga J, Kocsubé S, Anita R, Revathi R, Németh TM, Narendran V, Vágvölgyi C, Panneer Selvam K, Shobana CS, Babu Singh YR, Kredics L (2013) Epidemiology of Aspergillus keratitis at a tertiary care eye hospital in South India and antifungal 
susceptibilities of the causative agents. Mycoses 56:26-33. https:// doi.org/10.1111/j.1439-0507.2012.02194.x

Marchese S, Polo A, Ariano A, Velotto S, Costantini S, Severino L (2018) Aflatoxin $\mathrm{B}_{1}$ and $\mathrm{M}_{1}$ : biological properties and their involvement in cancer development. Toxins 10:214. https://doi.org/10.3390/ toxins 10060214

Massey TE, Smith GBJ, Tam AS (2000) Mechanisms of aflatoxin $B_{1}$ lung tumorogenesis. Exp Lung Res 26:673-683

McKean C, Tang L, Tang M, Billam M, Wang Z, Theodorakis CW, Kendall RJ, Wang JS (2006) Comparative acute and combinative toxicity of aflatoxin $\mathrm{B}_{1}$ and fumonisin $\mathrm{B}_{1}$ in animals and human cells. Food Chem Toxicol 44:868-876. https://doi.org/10.1016/j.fct.2005.11.011

Medina A, Rodriguez A, Magan N (2014) Effect of climate change on Aspergillus flavus and aflatoxin $\mathrm{B}_{1}$ production. Front Microbiol 5: 348. https://doi.org/10.3389/fmicb.2014.00348

Meissonnier GM, Pinton P, Laffitte J, Cossalter AM, Gong YY, Wild CP, Bertin G, Galtier P, Oswald IP (2008) Immunotoxicity of aflatoxin $\mathrm{B}_{1}$ : impairment of the cell-mediated response to vaccine antigen and modulation of cytokine expression. Toxicol Appl Pharmacol 231: 142-149-142-149. https://doi.org/10.1016/j.taap.2008.04.004

Murdock BJ, Falkowski NR, Shreiner AB, Sadighi Akha AA, McDonald RA, White ES, Toews GB, Huffnagle GB (2012) Interleukin-17 drives pulmonary eosinophilia following repeated exposure to Aspergillus fumigatus conidia. Infect Immun 80:1424-1436. https://doi.org/10.1128/IAI.05529-11

Olsen J, Dragsted L, Autrup H (1988) Cancer risk and occupational exposure to aflatoxins in Denmark. Br J Cancer 58:392-396. https://doi.org/10.1038/bjc.1988.226

Oppliger A, Rusca S, Charrière N, Vu Duc T, Droz PO (2005) Assessment of bioaerosols and inhalable dust exposure in Swiss sawmills. Ann Occup Hyg 49:385-391. https://doi.org/10.1093/annhyg/meh105

Palanee T, Dutton MF, Chuturgoon AA (2001) Cytotoxicity of aflatoxin $\mathrm{B}_{1}$ and its chemically synthesised epoxide derivative on the A549 human epithelioid lung cell line. Mycopathologia 151:155-159. https://doi.org/10.1023/A:1017985924257

Pariza MW, Johnson EA (2001) Evaluating the safety of microbial enzyme preparations used in food processing: update for a new century. Regul Toxicol Pharmacol 33:173-186. https://doi.org/10.1006/rtph.2001.1466

Paterson RRM, Lima N (2010) How will climate change affect mycotoxins in food? Food Res Int 43:1902-1914. https://doi.org/10. 1016/j.foodres.2009.07.010

Perrone G, Gallo A, Logrieco AF (2014) Biodiversity of Aspergillus section Flavi in Europe in relation to the management of aflatoxin risk. Front Microbiol 5:1-5. https://doi.org/10.3389/fmicb.2014.00377

Piecková E, Wilkins K (2004) Airway toxicity of house dust and its fungal composition. Ann Agric Environ Med 11:67-73

Qian G, Tang L, Guo X, Wang F, Massey ME, Su J, Guo TL, Williams JH, Phillips TD, Wang JS (2014) Aflatoxin $B_{1}$ modulates the expression of phenotypic markers and cytokines by splenic lymphocytes of male F344 rats. J Appl Toxicol 34(3):241-249. https://doi. org $/ 10.1002 /$ jat.2866

Rao CY, Fink RC, Wolfe LB, Liberman DF, Burge HA (2016) A study of Aflatoxin production by growing on wallboard. Journal of the American Biological Safety Association 2(4):36-42
Ren P, Ahearn DG, Crow Jr SA (1999) Comparative study of Aspergillus mycotoxin production on enriched media and construction material. J Ind Microbiol Biotechnol 23(3):209-213

Roilides E, Lamaignere CG, Farmaki E (2002) Cytokines in immunodeficient fungal infections: an emerging patients therapy. Int J Infect Dis 6:154-163

Samson RA, Houbraken J, Thrane U, Frisvad JC, Andersen B (2010) Food and indoor fungi. Fungal Biodiversity Centre Utrecht, The Netherlands

Samson RA, Visagie CM, Houbraken J, Hong S-B, Hubka V, Klaassen CHW, Perrone G, Seifert KA, Susca A, Tanney JB, Varga J, Kocsubé S, Szigeti G, Yaguchi T, Frisvad JC (2014) Phylogeny, identification and nomenclature of the genus Aspergillus. Stud Mycol 78:141-173

Schweer KE, Jakob B, Liss B, H2 C, Fischer G, Vehreschild M, Cornely OA, Vehreschild JJ (2016) Domestic mould exposure and invasive aspergillosis - air sampling of Aspergillus spp. spores in homes of hematological patients, a pilot study. Med Mycol 54:576-583. https://doi.org/10.1093/mmy/myw007

Sharma D, Dutta BK, Singh AB (2010) Exposure to indoor fungi in different working environments: a comparative study. Aerobiologia (Bologna) 26:327-337. https://doi.org/10.1007/ s10453-010-9168-9

Singh NP, McCoy MT, Tice RR, Schneider EL (1988) A simple technique for quantitation of low levels of DNA damage in individual cells. Exp Cell Res 175:184-191

Soares C, Rodrigues P, Peterson SW, Lima N, Venâncio A (2012) Three new species of Aspergillus section Flavi isolated from almonds and maize in Portugal. Mycologia 104:682-697. https://doi.org/10. 3852/11-088

Suganuma M, Okabe S, Marino MW, Sakai A, Sueoka E, Fujiki H (1999) Essential role of tumor necrosis factor a (TNF-a) in tumor promotion as revealed by TNF-a deficient mice. Cancer Res 59:4516-4518

Turner MD, Nedjai B, Hurst T, Pennington DJ (2014) Cytokines and chemokines: at the crossroads of cell signalling and inflammatory disease. Biochim Biophys Acta-Mol Cell Res 1843:2563-2582. https://doi.org/10.1016/j.bbamcr.2014.05.014

Van Vleet TR, Klein PJ, Coulombe RA (2002) Metabolism and cytotoxicity of aflatoxin $\mathrm{B}_{1}$ in cytochrome P-450 expressin human lung cells. J Toxicol Environ Health A 65:853-867. https://doi.org/10. 1080/0098410029007121

Varga J, Frisvad JC, Samson RA (2011) Two new aflatoxin producing species, and an overview of Aspergillus section Flavi. Stud Mycol 69:57-80. https://doi.org/10.3114/sim.2011.69.05

Viegas S, Veiga L, Malta-Vacas J, Sabino R, Figueredo P, Almeida A, Viegas C, Carolino E (2012) Occupational exposure to aflatoxin $\left(\mathrm{AFB}_{1}\right)$ in poultry production. J Toxicol Environ Health A 75: 1330-1340. https://doi.org/10.1080/15287394.2012.721164

Yu J, Bhatnagar D, Cleveland TE (2004) Completed sequence of a aflatoxin pathway gene cluster in Aspergillus parasiticus. FEBS Lett 564:126-130. https://doi.org/10.1016/S0014-5793(04)00327-8

Zhao M, Xia L, Chen GQ (2012) Protein kinase c delta in apoptosis: a brief overview. Arch Immunol Ther Exp 60:361-372. https://doi. org/10.1007/s00005-012-0188-8;10.1007/s00005-012-0188-8 